\title{
TOWARDS A WAR-FREE WORLD
}

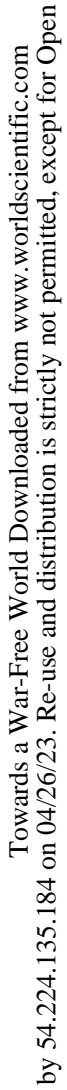


This page is intentionally left blank 


\section{TOWARDS A WAR-FREE WORLD}

\section{Annals of Pugwash 1994}

Edited by

\section{Joseph Rotblat}


Published by

World Scientific Publishing Co. Pte. Ltd.

P O Box 128, Farrer Road, Singapore 9128

USA office: Suite 1B, 1060 Main Street, River Edge, NJ 07661

UK office: 57 Shelton Street, Covent Garden, London WC2H 9HE

\section{British Library Cataloguing-in-Publication Data}

A catalogue record for this book is available from the British Library.

\section{TOWARDS A WAR-FREE WORLD}

\section{THE ANNALS OF THE 44TH PUGWASH CONFERENCE, 1994}

Copyright $\odot 1995$ by World Scientific Publishing Co. Pte. Ltd.

All rights reserved. This book, or parts thereof, may not be reproduced in any form or by any means, electronic or mechanical, including photocopying, recording or any information storage and retrieval system now known or to be invented, without written permission from the Publisher.

For photocopying of material in this volume, please pay a copying fee through the Copyright Clearance Center, Inc., 222 Rosewood Drive, Danvers, MA 01923, USA.

ISBN 981-02-2492-3

Printed in Singapore. 


\section{TOWARDS A WAR-FREE WORLD}

Contents

Preface

vii

Notes on the Contributors

ix

Abbreviations and Acronyms

xi

Part I - Towards a Nuclear-Weapon-Free World

Georgi Arbatov

Towards A War-Free World: A View from Russia

Maj Britt Theorin Prevention of Proliferation: The NPT Review

Conference and After; CTBT

Julio Carasales

Some Thoughts on the Approaching NPT 1995

Extension Conference

Krishnaswami

Prevention of Proliferation: The NPT Review

Subrahmanyam

Conference and After; CTBT

Jozef Goldblat

How to Render Nuclear Weapons Illegal

Part II - Conventional Arms Reduction and Control

Jo Husbands

Arms Transfers in a Time of Transition:

The Context for Controls

Jasjit Singh Managing the Transfer of Arms

Jeffrey Boutwell

The Global Trade in Small Arms and Light Weapons

Alexander Nikitin Non-Traditional Peace-keeping

\section{Part III - Local and Global Governance}

Toshiki Mogami The Democratic Reform of the UN

Omran El Shafei Greater Roles of the UN in the Prevention and Resolution of Conflict

Marti Rabinowitch The Role of Non-Governmental Organizations in Governance 
vi

Douglas Roche Education for World Citizenship and Global

Responsibility

Ana Maria Cetto Dialogue Between Histories

Part IV - Towards Sustainability: World Resources and the Environmental Problem

Noah Cox-George The New Economic Order: Internationalization of

Environmental Costs

Mikulas Huba

The Environment - A New Dimension To Global Security

Alfred Schmidt

Sustainable Development

\section{Part V - Regional Confidence-Building Measures}

Klaus Gottstein Control of Regional Conflicts by Confidence-Building Measures

Nansen Behar

Confidence and Security-Building Measures in the Balkans

Sverre Lodgaard Confidence-Building and Arms Control in the Middle East

Marie Muller

Sources of Tension and Conflict in Southern Africa and Possible Confidence-Building Measures

\section{Part VI - Ethical Challenges}

Roger Williamson Ethics, Survival and Belligerence: Faith and Dogma as a Source of Collaboration and Conflict

Gerald Barney The Parliament of the World's Religions, The Millenium Institute and the Future of the Earth

Serguei Kapitza Population Dynamics and the Future of the World

\section{Appendix}

Statement of the Pugwash Council on the 44th Conference 


\section{PREFACE}

The theme of the 44th Annual Pugwash Conference, held in July 1994 in Crete, was "Towards a War-Free World. " The main effort of Pugwash in recent years has been directed towards the creation of a nuclear-weapon-free world (NWFW), and even this - much more limited - objective is still far from being achieved. Nevertheless, it is important to keep the ultimate objective in mind while pursuing the more immediate goals. In this particular case, the societal changes that will have to be introduced on the way to achieving a NWFW will also pave the way towards general and complete disarmament.

Actually, only one paper was presented at the Conference which dealt directly with the problem of a weapon-free world. This was written by a Russian veteran analyst and presented a view from Russia. Considering the chaotic situation existing in post-Cold War Russia, an opinion coming from there is bound to be pessimistic, even cynical, but surprisingly it is not dismissive of the idea of a war-free world, and it encourages collaboration towards it.

The bulk of the papers in this volume discuss the variety of steps that need to be taken on the way to a war-free world. These include international control of conventional weapons and the arms trade, and problems of world governance, but nuclear issues commanded much attention, in particular the problem of proliferation of nuclear weapons. Most of the papers in Part I were concerned with the decision to be taken at the Extension Conference in April/May 1995, on whether the Non-Proliferation Treaty, which is then coming to an end, should be extended indefinitely and unconditionally, or conditionally for a limited period or periods. There are strong arguments for and against both alternatives, but while there was no consensus in Pugwash on this issue there was general agreement that the nuclear weapon states must demonstrate at the Extension Conference a stronger commitment to general nuclear disarmament. The relevant question of the legality of the use of nuclear weapons is discussed in one paper, which includes the history of the various treaties and conventions relevant to nuclear warfare.

Whilst nuclear weapons pose a potential threat, conventional weapons are actually used all the time in the various current conflicts. The problem of the control of these weapons is the theme of the papers in Part II. It starts off with a comprehensive review of the production of arms and their international transfer, and the prospect of control of the arms trade. The need for a UN Register of small arms is stressed, leading in particular to the ban on the use of land mines and other indiscriminate weapons. A dedicated UN force to be concerned with these matters is recommended.

This leads on to Part III which is concerned with the development of more effective mechanisms for conflict resolution at global and local levels. A much greater role for the UN in preventing conflicts is evaluated and strongly advocated. One paper, after an erudite analysis of various means of governance, recommends a fundamental reorganization of society in which NGO's would play a major role. The basic issue of global governance is examined in another paper, which calls for a new global ethic, and for education for world citizenship. The last paper in this section considers the different ways in which the concept of global citizenship is viewed by people from different countries.

Part IV is concerned with problems which mainly affect the less developed countries. There is an analysis of the New International economic Order, in theory and in practice, and 
viii

a critical assay of the recommendations of the recent UN Conferences on environmental problems. This and other papers come to the conclusion that new approaches are needed at all levels, local, national and international. One paper goes into detail about sustainable development, mainly in regard to the depletion of natural resources and the pressing need to develop renewable energy resources.

The need for the creation of a climate conducive to the peaceful settlement of conflict is the essence of Part V, which deals with confidence-building measures, particularly at the regional level. After a general examination of the role of confidence-building measures in regional conflicts, three papers examine this issue in specific regions: the Balkans, the Middle East and Southern Africa.

Part VI is concerned with an entirely different issue, but relevant to all problems debated in Pugwash: the ethical challenges they pose. There is an extensive and erudite, largely philosophical, examination of the ethical dilemmas for modern society when dealing with conflicts. The role of religion in these matters comes under scrutiny. Religion is of course involved in one of the most intractable issues facing modern society: control of population growth. The importance of demographic factors in any future world order is discussed in another paper. Finally, in connection with the approaching end of the millennium, specific plans are described for a Millennium Institute in conjunction with the Parliament of the World's Religions.

The papers in this volume were extensively discussed at plenary sessions or in the Working Groups of the Conference. The outcome of these discussions is summarized in the appended Statement, issued by the Pugwash Council at the conclusion of the Conference. The authors of the chapters in this book participated in the Conference in their personal capacity, and the views expressed are their own. Finally, the Council Statement does not represent a consensus of the Conference but only of the members of the Council.

In editing this volume I was immensely helped by Tom Milne and David Rule, who have also prepared the camera-ready copy of the text. I wish to express my great indebtedness to them. I am also grateful to Sue England for her help in preparing the index.

Joseph Rotblat 


\section{Notes on the Contributors}

Georgi Arbatov (Russia): international relations; Director, Institute of the United States of America, Moscow

Gerald Barney (USA): political science; Executive Director, Millenium Institute, Arlington, Virginia

Nansen Behar (Bulgaria): international relations; Director, Institute for Social and Political

Studies, Sofia; Dean, Faculty of Public Administration, University of Blagoevgrad

Jeffrey Boutwell (USA): international relations; Associate Executive Officer, American Academy of Arts \& Sciences

Julio Carasales (Argentina): diplomacy; Ministry of Foreign Affairs; former Under-secretary of Foreign Affairs

Ana Maria Cetto (Mexico): physics; Head of Department of Theoretical Physics, Instituto de Fisica, Mexico D.F.

Noah Cox-George (Sierra Leone): economics; former Professor of Economics at the University of Nigeria, Nusuka and the University of Sierra Leone

Omran El-Shafei (Egypt): international relations; Member, UN Advisory Board on Disarmament Matters; former Assistant Foreign Minister

Jozef Goldblat (Switzerland): arms control; Senior Lecturer and Research Fellow, The Graduate Institute of International Studies, Geneva

Klaus Gottstein (Germany): physics/science policy; former Director, Gottstein Research Unit, Max-Planck Gesellschaft

Mikulas Huba (Slovakia): geography; Scientific worker, Institute of Geography, Slovak Academy of Sciences; former Member, Presidium of the Slovak Parliament

Jo Husbands (USA): international relations; Director, Committee on International Security and Arms Control, National Academy of Sciences

Serguei Kapitza (Russia): physics; Institute for Physical Problems, Russian Academy of Sciences; President of Eurasian Physical Society

Sverre Lodgaard (Norway): international relations; Director, United Nations Institute for Disarmament Research, Geneva 
Toshiki Mogami (Japan): peace studies; Professor at International Christian University, Peace Research Institute, Tokyo

Marie Muller (South Africa): international relations; Senior Lecturer in Department of Political Science, University of South Africa, Pretoria

Alexander Nikitin (Russia): international relations; Centre for Political and International Studies, Moscow; former Senior Research Fellow, USA \& Canada Institute, Russian Academy of Sciences

Marti Rabinowitch (USA): international relations; Senior Adviser, The John D and Catherine T MacArthur Foundation

Douglas Roche (Canada): diplomacy; Visiting Professor, University of Alberta; former Canadian Ambassador for Disarmament

Joseph Rotblat (UK): physics; Emeritus Professor of Physics at the University of London; President, Pugwash Conferences on Science and World Affairs

Alfred Schmidt (Austria): chemical engineering; Head, Department of Chemical and Fuel Engineering, Technical University of Vienna; President, Austrian Chemical Society

Jasjit Singh (India): international relations; Institute for Defence Studies \& Analyses, New Delhi

Krishnaswami Subrahmanyam (India): international relations; Consulting Editor, Economic Times, New Delhi; former Director, Institute for Defence Studies \& Analyses, New Delhi

Maj-Britt Theorin (Sweden): politics; Member, Swedish Parliament; President, International Peace Bureau; former Swedish Ambassador for Disarmament

Roger Williamson (UK): arms control; former Director, Council for Arms Control, London 


\section{ABBREVIATIONS AND ACRONYMS}

$\begin{array}{ll}\text { ABM (Treaty) } & \text { Anti-Ballistic Missile (Treaty) } \\ \text { ACDA } & \text { Arms Control and Disarmament Agency } \\ \text { ANC } & \text { African National Congress } \\ \text { BWC } & \text { Biological Weapons Convention } \\ \text { CBM } & \text { confidence-building measure } \\ \text { CBW } & \text { chemical and biological weapons } \\ \text { CD } & \text { Conference on Disarmament (in Geneva) } \\ \text { CFE (Treaty) } & \text { Conventional Forces in Europe (Treaty) } \\ \text { CIS } & \text { Commonwealth of Independent States } \\ \text { CSBM } & \text { confidence- and security-building measure } \\ \text { CSCE } & \text { Conference on Security and Cooperation in Europe } \\ \text { CTB (T) } & \text { comprehensive test ban (treaty) } \\ \text { CWC } & \text { Chemical Weapons Convention } \\ \text { EU } & \text { European Union } \\ \text { GDP } & \text { gross domestic product } \\ \text { GNP } & \text { gross national product } \\ \text { HEU } & \text { highly-enriched uranium } \\ \text { IAEA } & \text { International Atomic Energy Agency } \\ \text { ICBM } & \text { inter-continental ballistic missile } \\ \text { ICJ } & \text { International Court of Justice } \\ \text { IMF } & \text { International Monetary Fund } \\ \text { INF (Treaty) } & \text { Intermediate-Range Nuclear Forces (Treaty) } \\ \text { NATO } & \text { North Atlantic Treaty Organization } \\ \text { NGO } & \text { non-governmental organization } \\ \text { NIEO } & \text { new international economic order } \\ \text { NPT } & \text { (Nuclear) Non-Proliferation Treaty } \\ \text { NWFW } & \text { nuclear-weapon-free world } \\ \text { NWFZ } & \text { nuclear-weapon-free zone } \\ \text { OECD } & \text { Organization for Economic Cooperation and Development } \\ \text { OTA } & \text { Office of Technology Assessment } \\ \text { PTB(T) } & \text { Partial Test-Ban (Treaty) } \\ \text { SIPRI } & \text { Stockholm International Peace Research Institute } \\ \text { START } & \text { Strategic Arms Reduction Treaty } \\ \text { UNCED } & \text { United Nations Conference on Environment and Development } \\ \text { UNCTAD } & \text { United Nations Conference on Trade and Development } \\ \text { WUFUNA } & \text { World Federation of UN Associations } \\ & \end{array}$

